\title{
Suggested landfill sites for hazardous waste in Iraq
}

\author{
Nadhir Al-Ansari", Roland Pusch, Sven Knutsson \\ Department of Civil, Environmental and Natural Resources Engineering, Luleå University of Technology, Luleå, Sweden; \\ *Corresponding Author: nadhir.alansari@1tu.se
}

Received 6 February 2013; revised 10 March 2013; accepted 20 March 2013

Copyright (C) 2013 Nadhir Al-Ansari et al. This is an open access article distributed under the Creative Commons Attribution License, which permits unrestricted use, distribution, and reproduction in any medium, provided the original work is properly cited.

\begin{abstract}
Iraq experienced two devastating wars in 1991 and 2003, during which massive amounts of new weapons and sophisticated manufactured nuclear weapons were used called Depleted Uranium (DU). As a consequence of the radioactive contamination; the humans are suffering from various disease like cancer and the environment is polluted. In practice, there is no strategy andl or national program, not even well thought out plans and scientific personnel and technical equipment required to clean Iraq of these wastes. Reviewing the geological, topographical and hydrological data, we have noticed that Umm Chaimin depression is a good candidate site to dump all contaminated radioactive scrap and soil. The suggested design of the landfill will ensure safe containment of the waste for hundreds of thousands of years even if significant climatic changes take place.
\end{abstract}

Keywords: Iraq; Umm Chaimin; Depleted Uranium; Landfill; Site Selection Criteria

\section{INTRODUCTION}

Solid waste is generated in many forms by human activities (Industrial, domestic, commercial and construction) and animals. Some of the waste fall out of the commercial use i.e. cannot be utilized. Parts of this waste (specially the industrial part) are considered hazardous to the environment and natural resources. Continuous population growth and increase of standard of living, solid waste is increasing in tremendous amounts. This fact enforced a major problem facing the world.

The problem is particularly serious in third world countries where $80 \%$ of the world population lives [1,2] and where the lack of financial resources is significant. It is believed that about $10 \%$ of each person's production life is lost as a result of waste related diseases [1]. These facts led to an increasing awareness of solid waste hazards on an international level. Consequently, legislations and laws developed since the mid of the twentieth century (e.g. UN conference in Stockholm, 1972; Earth Summit in Rio de Janeiro, 1992, in [3]). It is noteworthy that improper solid waste management will cause air, soil and water pollution. The overall objectives of such measures are to ensure sustainable development and management of waste in a sound manner in order to minimize its effects on human beings and the environment.

According to the Organization of Economic Co-Operation and Development (OECD), USA and Canada produce more waste than other countries. They are followed by Western Europe, Japan and Korea Australia and New Zealand (Figure 3). In year 2000 hazardous waste production was about 150 million tons per year [4] (Figure 5).

Radioactive waste is an important part of hazardous rest products. The source of radioactive waste includes nuclear power plants, industry, hospitals, research organizations and military nuclear tests and weapons [5]. IAEA [6] published in 1995 the ethics and principles for the management and disposal of these wastes irrespective of their physical and chemical characteristics or origin minimizing the risks to population and environment. Individual countries also have their own policy principles that might include administrative and operational measures based on national priorities, structure and human and financial resources. Declarations and agreements were executed to prevent radioactive pollution $[7,8]$. Nuclear power plants are dangerous facilities put in practical use on the stipulation that they can "completely seal in radiation", while radioactive weapons commit an impermissible crime scattering radioactive materials in the environment [9]. Currently there are 441 power reactors in operation and some under construction (IAEA, 2011). The Global radioactive waste inventory reported as storage in 2008 was 17.6 million cubic meters [10]. Of these $21 \%$ are short-lived, low and intermediate level waste, 
$77 \%$ long-lived, low and intermediate level waste, and $2 \%$ high level waste [11].

DU (depleted uranium) has been used in weapons due to its ability to penetrate armored vehicles, tanks and bunkers $[12,13]$. On explosion it creates a poisonous radioactive cloud of fine dust that can spread by tens of kilometers [12]. Anybody who breathes these particles will have a permanent dose; it is not going to decrease very much over time, and cause major problems $[13,14]$.

It is well known that (DU) had been used in military operation in various countries [5]. Depleted uranium is a by-product of the enrichment of natural uranium for nuclear reactor or nuclear weapons. It is chemically identical to natural uranium. In DU most of the 235 isotope has been extracted leaving mainly the non-fissionable 238 isotope. It is used for manufacturing tips of armor-piercing shells because of it's extremely density: 1.7 times denser than lead. In addition, unlike other heavy metals that tend to flatten, or mushroom; upon impact, DU has the ability to "self-sharpen" as material spreads out by the impact. It ignites and burns off as the munition pierces its target [14-16].

Although DU is 40 percent less radioactive than natural uranium, its radiological and toxic effects might combine in subtle, unforeseen ways, making it more carcinogenic than thought.

Depleted Uranium is "genotoxic". It chemically alters DNA, switching on genes that would otherwise not be changed. The fear is that the resulting abnormally high activity in cells may be a precursor to tumor growth.

Depleted uranium weapons alloy is $99.8 \%$; U238, emitting $60 \%$ of the alpha, beta, and gamma radiation of natural uranium $[15,17]$. When the DU penetrates an object it breaks up and causes secondary explosions. Some of the uranium used in DU weapons vaporizes into extremely small particles, which are dispersed into the atmosphere where they remain until they fall to the ground with rain. Uranium in gaseous form oxidizes and can enter the body through the skin or the lungs and be carried around the world until it falls to the ground.

DU is used in many forms of ammunition as an armor penetrator because of its extreme weight and density. The depleted uranium used in these missiles and bombs is a by-product of the nuclear enrichment process. Experts say that the US Department of Energy has 100 million tons of DU and using it in weapons saves the government's cost for ordinary disposal $[18,19]$.

In 1980, the US army started to test the capacity of DU as an armor penetration weapon instead of expensive tungsten. It is illustrated by the fact a flying rod $30 \mathrm{~mm}$ in diameter of DU can penetrate a $9 \mathrm{~cm}$ thick steel plates and since this time the US army is using DU in different ammunition forms. Other countries followed e.g. UK, France, Russia, Israel, Taiwan, proposed use of the tail- ings which could be molded into bullets and bombs. The material was free for use and there was plenty at hand. DU is perfect for use in armor-penetrating weapons, designed to destroy tanks, armored-personnel carriers and bunkers [20].

When the tank-busting bombs explode, the depleted uranium oxidizes into microscopic particles that float through the air like carcinogenic dust, carried on the desert winds for decades. The lethal bits when inhaled stick to the fibers of the lungs, and eventually begin to generate tumors, hemorrhages, ravaged immune systems and leukemia. More than 30 percent of the DU fired from the cannons of US tanks is reduced to particles one-tenth of a micron in size or smaller on impact. The amount of DU that is dispersed into the atmosphere is directly related to the size of the bang. With the larger missiles and bombs, nearly 100 percent of the DU is reduced to radioactive dust particles of the "micron size" or smaller. Depending on their size, inhaled particles of radioactive uranium oxide dust will either lodge in the lungs or travel through the body. The smallest particles can be carried through cell walls and affect the master code - the expression of the DNA [14,21].

DU debris raises child cancer and other illness rates in Europe and the Middle East. DU's fine particles can also be harmful to the lungs, lymph nodes, kidneys, skin, and the lenses of the eyes. When inhaled or swallowed by humans, animals or fish, such dust can create serious and permanent health hazards. Expended DU is a permanent terrain contaminant with a half-life of 4.5 billion years. Depleted Uranium dust can linger in the lungs, lymphnodes, bones, blood and other organs for years. It is reported to have caused some of the so-called mysterious ailments among the more than 350,000 US service members, many of whom unsuccessfully sought medical treatment after the second Gulf War. At least four states (New York, California, Louisiana and Connecticut) tried to force the US Department of Defense to better test and care for Gulf war veterans for DU exposures. Their legislatures and governors were all concerned about sick service members exposed to DU wartime dust [15].

Corroding DU penetrators embedded in the ground might pose a long-term threat if the uranium leaches into water supplies. After shell firings, the ground becomes polluted with depleted uranium particulate waste and some parts of the munitions themselves. DU contamination should be removed from areas around known penetrator impact sites. Long-term environmental sampling, particularly of water and milk, is required and provides a cost-effective method of monitoring sensitive components of the environment, and of providing information about uranium levels to concerned local populations. Monitoring may need to be enhanced in some areas, by site-specific risk assessment, if the situation warrants fur- 
ther consideration.

Since 1999 several attempts were made by United Nations committee for a DU munitions ban worldwide because its long-term adverse health impact on civilians violates international law. In 2002, the World Health Organization recommended that "young children's exposure to depleted uranium must be monitored and preventive measures taken, and heavily affected impact zones for depleted uranium munitions should be cordoned off and cleaned up" [21]. According to Afghanistan doctors the rates of some health problems affecting children have doubled in the last two years. Some researchers believe that this is linked to use of weapons containing depleted uranium (DU) by the US-led coalition that invaded the country in 2001. Very high levels of uranium in Afghans were noticed by a Canadian research group during tests just after the invasion [22,23].

The European Parliament passed a global ban on such weapons with a landslide approval vote. There have been serious concerns about the radiological and chemical toxicity of the fine uranium particles produced when such weapons impact on hard targets ever since its use by the allied forces in the first war against Iraq. In addition, concerns have also been expressed about the contamination of soil and groundwater by expended rounds that have missed their targets and their implications for civilian populations [12]. DU had been used in Iraq as a result of the gulf wars [24-28]. The aim of this research is to execute a relatively cheap technique to burry contaminated radioactive military scrap in Iraq to save the civilians and the environment.

\section{DEPLETED URANIUM (DU) IN IRAQ}

\subsection{Locations}

Depleted uranium (DU) has been used in Iraq as a result of the gulf wars [24-27]. Iraq is located between geographic coordinates $3300 \mathrm{~N}, 4400 \mathrm{E}$, (Figure 1), and occupies a total area of 437,072 square kilometers. The total population in Iraq is about $30,000,000$. The majority of the people live in cities on the banks of the Tigris and Euphrates Rivers.

DU was used twice by the Americans and allied forces against Iraqi troops and personnel in 1991 and 2003. The largest single radionuclide contamination occurred in the Gulf during Gulf War II, 1991, where depleted uranium was used as amour-penetrating ordnance, contaminated the countryside of Iraq, and chronically exposed the civilian population and military personnel to DU dust, vapors, and aerosols.

During the second Gulf war in 2003 US and British troops have reportedly used more than five times as many DU bombs and shells as the total number used during the 1991 war for the invasion and occupation of Iraq.

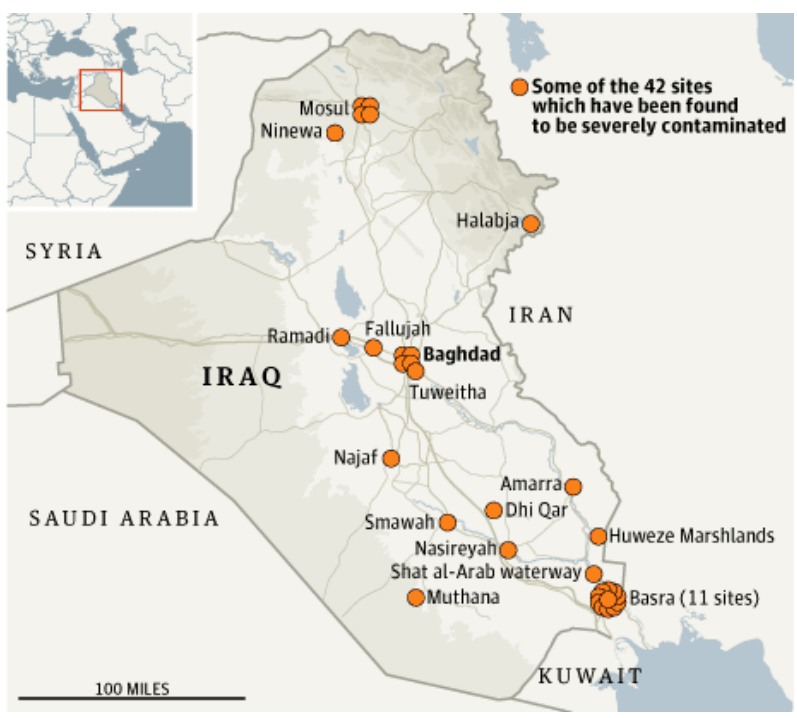

Figure 1. Contaminated sites in Iraq with DU [29].

It was estimated that more than 1100 to 2200 tons of DU was used. This quantity is 400 to 800 more powerful than the ones used in the first Gulf war. According to Okinawa [30] every 800 tons of DU is equivalent to $83 \mathrm{nu}-$ clear bombs. Accordingly, about 250 nuclear bombs were fired on Iraq tell 2003 war.

Weyman [31] reported that the Uranium Medical Research Center cited in their report that the published data about the quantities of DU used in Iraq are as follow:

- 24 Imperial Tons (21.8 Metric Tonnes). US Army data related by US Senator Jon Kyle, US Senator, Chair of the Republican Policy Committee, in a letter to J. Cohen-Joppa, July 14, 2003.

- 100 - 200 Metric Tonnes-D. Fahey, the Use of Depleted Uranium in the 2003 Iraq War: An Initial Assessment of Information and Policies, June 24, 2003.

- 68 Metric Tonnes (75 Imperial Tons), representing calculations based on \% of DU rounds loaded in total fired rounds of 300,000 by A-10 Thunderbolt. Reported interview of unnamed CentCom spokesperson, Christian Science Monitor, May 15, 2003.

- 311,597 30-mm rounds, T M Mosley, USAF, By the Numbers, Operation Iraqi Freedom, Assessment and Analysis Division, USAF, April 2003.

- 1000 - 2000 metric tons (1100 - 2200 imperial tons), posted in Associated Press article, The Environment in the News, UNEP Environmental Press Release Reports, Communications and Public Information, United Nations Environment Program, Associated Press, April 2003.

Scherrer [32], cited based on the report of the 48th meeting issued by the UN Committee dealing with effects of Atomic radiation on 20th April 1999, noting the rapid increase in mortality caused by DU between 1991 and 1997, the IAEA document predicted the death of half 
a million Iraqis, noting that “...some $700-800$ tons of depleted uranium was used in bombing the military zones south of Iraq. Such a quantity has a radiation effect, sufficient to cause 500,000 cases which may lead to death."

Despite this red alert and explicit scientific evidence of the horrific effects of uranium weapons, the US continued to use DU weapons of mass destruction in Bosnia 1995, Yugoslavia/Serbia 1999 and Afghanistan from October 2001.

The exact location that had been contaminated are spreading from south to north of Iraq (Figure 1).

UMRC [23] conducted a team to investigate the areas contaminated by DU [31]. The team performed radiation surveys, nuclide analysis, interviewed civilians and community leaders, collected biological and field samples, and investigated the possible health effects of radiological weapons on Iraqi civilians. The types of locations investigated include:

- Ground-zero of acquired targets of the air bombing campaign;

- Disabled Iraqi armored assets and their defensive positions;

- Suburban, inner-city and agricultural areas that served as battlefields;

- Locations subject to both aerial bombing and ground combat;

- Collateral damage sites;

- Military facilities, air force bases and the perimeters of Coalition occupied bases;

- Down-wind and wide-area environments potentially subject to atmospheric, surface soil and ground water contamination.

UMRC's team surveyed bombsite and battlefield investigations, and sample collection activities were conducted in central and southern Iraq, covering major areas of engagement. Operation Iraqi Freedom executed two operational programs: "Rapid Dominance" and "Shock and Awe"; each was investigated by UMRC (Table 1).

As far as the "Rapid Dominance" is concerned the team traversed Iraq from the south to the north, beginning at the Gulf, Al Fau peninsula, and Coalition entry points at the port of Umm Qasr and the UN Demilitarized Zone at the Kuwaiti border adjacent to Al Zubair. Then they proceeded northerly along the Shaat al Arab corridor to sites of engagement led by the British forces approaching the city of Al Basra. Further investigation

Table 1. Bomb sites, battlefields and communities surveyed and investigated by UMRC September 30 to October 13, 2003 [25].

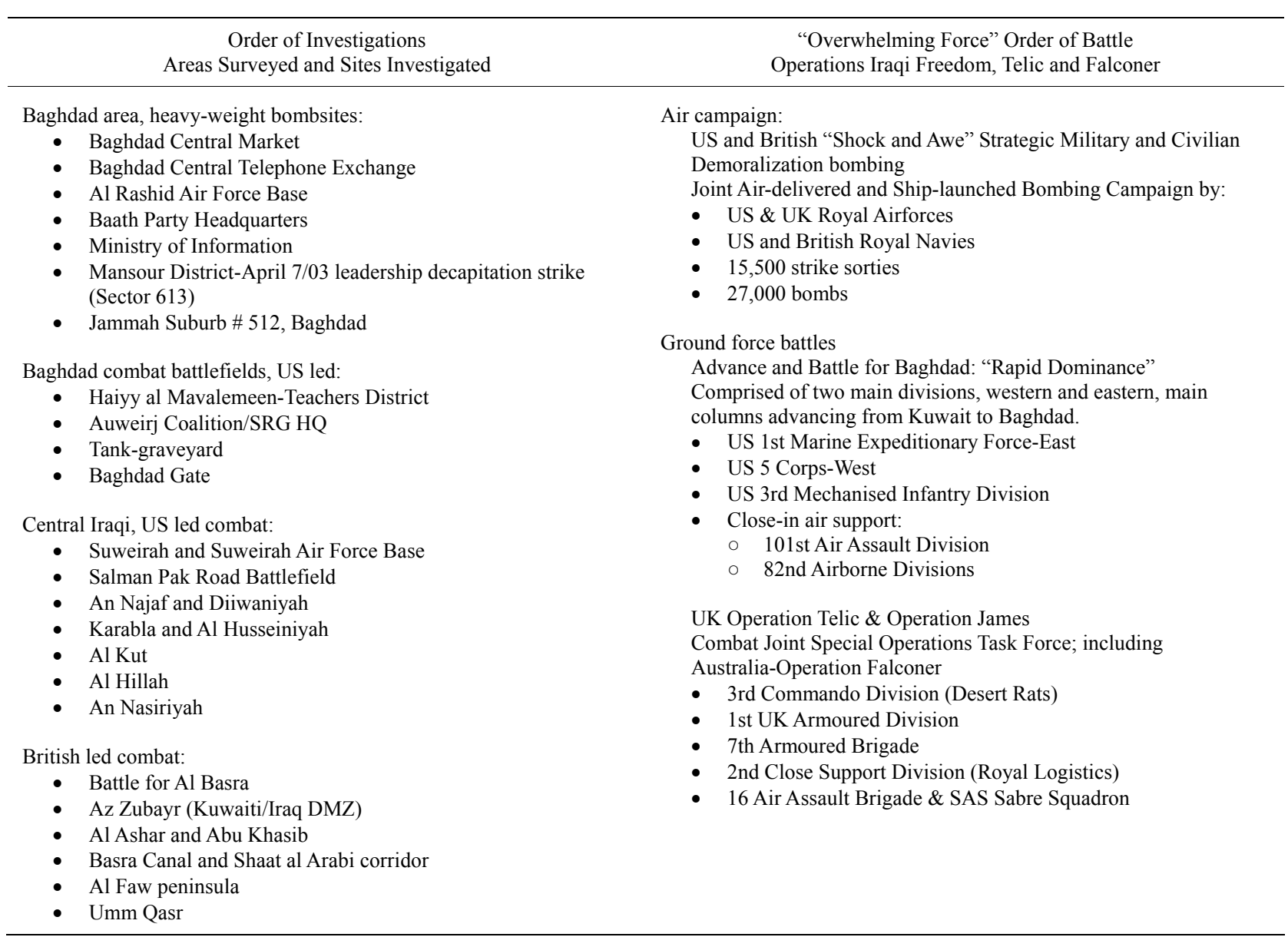


was carried out north to Al Nasiriyah where the US mechanized main column divided its forces into three: north-easterly along the Tigris River, north-westerly along the Euphrates River and centrally through the uplands of Mesopotamia. Along each route battlefields were surveyed, westerly through As Samawah to Al Najf, centrally through Karbala and As Suweirah, and easterly through Al Kuts and Al Hillah. Furthermore, they investigated a major combat area 60 kilometers south of Baghdad which was not reported during the war in the fertile plain of the Al Suweirah agricultural area. At the southerly approach-point to Baghdad, where the main northbound highways from the east and west converge at Baghdad Gate, the team made concentrated efforts also.

For the "Shock and Awe" (the air-delivered and shipand submarine-launched bombing campaign) the field team investigated radiation levels at some of the highly publicized strategic military and civilian demoralization targets in Baghdad. In these places the explosions of ship-launched weapons such as the TLAM-Tomahawk Land Attack Munitions, and the air-delivered, precision guided bombs-primarily the CALCM-Conventional Air launched Cruise Missile, J-DAM-Joint Direct Attack Munitions, JSOW-Joint Stand-Off Weapons, and the newly deployed British bunker-buster called the Storm Shadow-were took place [33]. The Iraqi nuclear facilities were destroyed using DU munitions (Figure 2). This gave different levels of radioactive contamination ranging from low to high radiation [33].

In addition to the radioactive contamination due to military activities in Gulf war II and III, other dangerous source of contamination was from the material and equipment at the Iraqi Energy Authority (Figure 3 and 4).

After the fall of the Baath regime in 2003, the Iraqi Energy Authority, like all other Ministries and governmental organizations, sustained immense losses due to the turmoil and looting.

The Middle East Media Research Institute (MEMRI) [34] carried out an intensive interview with formal researchers at the Iraqi Energy Authority and they disclosed the events that took place after the fall of Baath regime at the facilities of the commission. Tons of Uranium (as yellow cakes) as well as byproducts from processing activities in addition to tons of radioactive waste were stored in barrels. Simple citizens stolen these barrels and used they for storing water. The radioactive materials in these barrels were either spread in large quantities on the ground or taken to their homes. Later some of these barrels were used for drinking water while the others were used to sell milk. Some the researchers surveyed homes of some civilians and noticed that the contaminated barrels were used to store food or daily household. When they were told that these barrels are contaminated they throw some of them in the river and

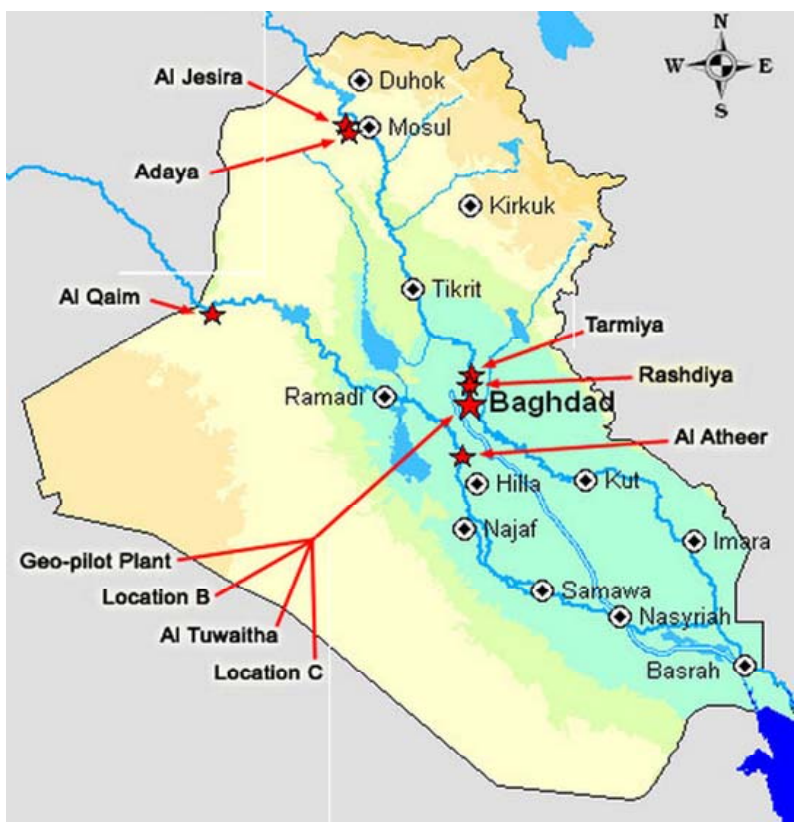

Figure 2. Locations of nuclear facilities in Iraq (Source, http://www-ns.iaea.org/images/rw/iraq/map-images/map_01.jpg).
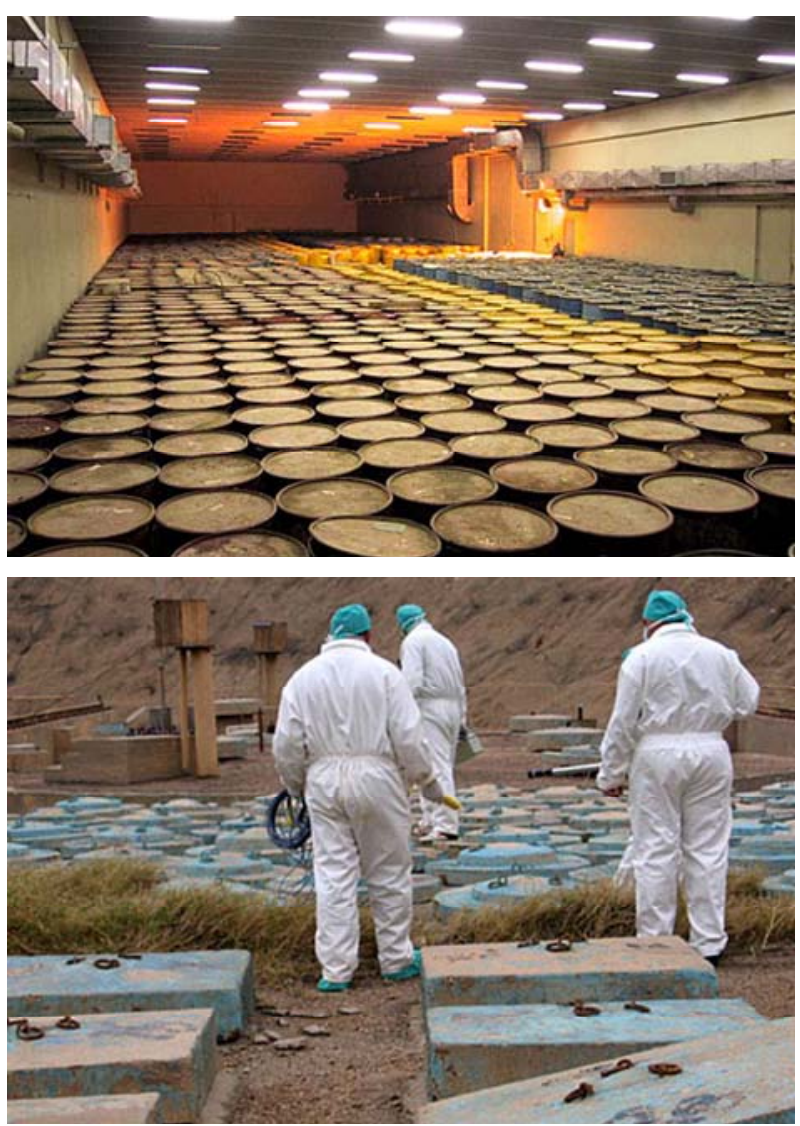

Figure 3. Left, waste barrels comprised of two groups, first; ready to use material (known as yellow cake), second; waste material stored in plastic barrels. Right, decayed solid and liquid radioactive wastes stored at Al-Tuwaitha site-waste silos (www.iaea.org). 

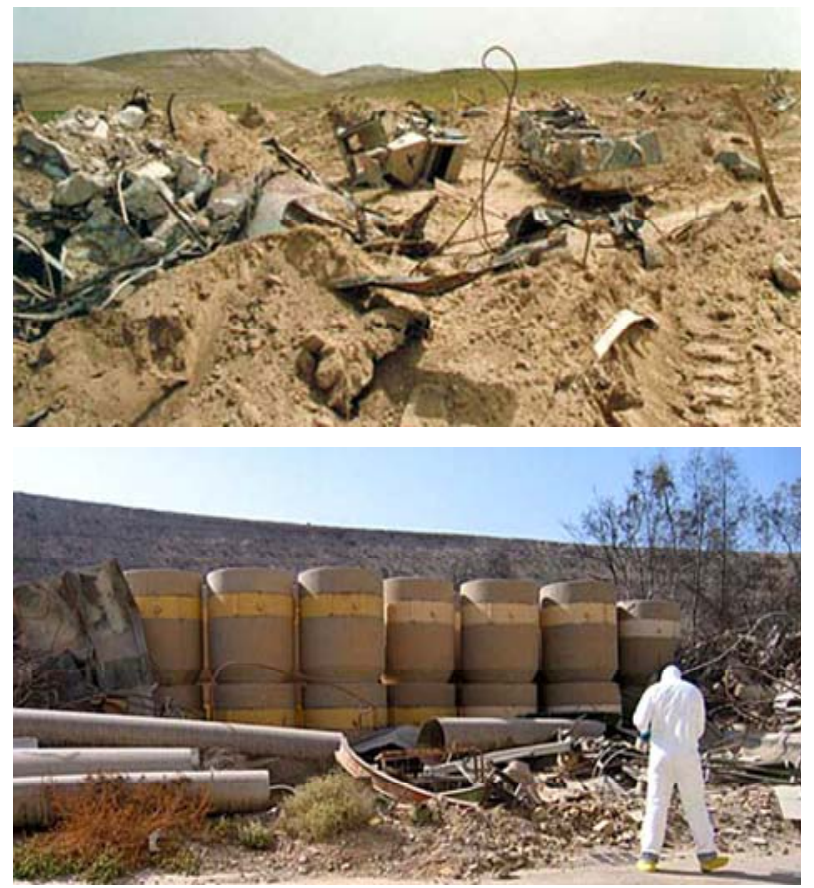

Figure 4. Left radioactive scrap and soil at Adaya site northern Iraq. Right, soil contamination at Al-Tuwaitha site-RWTS Warehouse near Baghdad (www.iaea.org).

others in waste sewer systems. About $4-5$ houses were tested for outdoor contamination every day. The level of radioactivity on the walls of one of the houses was 30 billion/hour (the allowed level is 0.2 ) which means that it was 150 million times more than the allowed level.

In other parts of the Iraqi Energy Authority, there were about 200 barrels of isotopes and radioactive materials as well as yellow Uranium Oxides; they were all spilled on the ground. If a strong wind blows, it can carry these quantities to great distances outside.

In addition, insects were kept in 4 labs where these insects were used as biological insecticides. The expected ecological disaster from releasing thousands of flies known as chrysomya bezziana, nicknamed screw worm, which were bred by the Nuclear Authority to be used as biological farming insecticides. They Iraqi police and the Americans were fully informed about these labs but nothing was done to protect the people from these harmful insects. The flies were released by the looters and were expected to harm animals in Iraq and neighboring countries. These flies were to be released after being sterilized [31]. Hall in 2006 reported that with the arid climate of Iraq, sandstorms blow tiny particles of DU away from the blast epicenter, impacting the surrounding environment without geographical limitations. These particles enter the soil, polluting the water table, the Tigris and Euphrates Rivers, and infecting the food chain. Fertile grasslands west of Basra in southern Iraq, contaminated with DU, produce vegetables and grains for livestock that are consumed by American troops as well as Iraqis [31].

The New York State National Guard Rainbow Division spent six months stationed in Camp Forward Danger on the Tigris River near Tikrit, north of Baghdad. This city being Saddam Hussein's rebellious hometown was the site of major combats using DU munitions during the initial invasion and for months afterward. During this period the soldiers were taking radioactive showers and washed small open wounds in a depleted uranium broth. They have eaten over 500 meals with food, plates and silverware washed with hot water, in two senses of the word. So now the Tigris River, the Bible's Edenic River of life, has become a modern river of death and the people there are drinking the forbidden water, without knowing it.

\subsection{Victims}

Hall [19] stated that no place in Iraq is free from radioactive contamination, even in what is referred to as the "safe" Green Zone in Baghdad where top military officers, civilian occupation authorities, international journalists, and the Iraqi government leaders live and work. In 1991 the Gulf War I resulted in 350 metric tons of DU deposited in the environment and about 3 to 6 million grams of DU aerosol released into the atmosphere. This caused what was later known as the Gulf war disease. These methods, identifying $0.2 \%-0.33 \%$ of U235 in Gulf War I veterans, demonstrate uranium concentration of $150 \mathrm{ng} / \mathrm{L}$ at the original time of exposure, as compared to the non-exposed population in the Gulf who contained $0.7 \%$ to $1.0 \%$ of $235 \mathrm{U}$, indicating a urinary uranium concentration of $14 \mathrm{ng} / \mathrm{L}$ [17]. The long physical and biological half-life, alpha particle decay, and well-established evidence of somatic and genetic radiation toxicity suggest a viable potential role of DU in the genesis of Gulf War and Balkan Syndromes [17].

The armor-piercing shells made of depleted uranium, which were first used in warfare by US-led troops during the1991 Gulf War and then during the 2003 invasion, turned many parts of Iraq to radioactive, toxic wastelands. Many soldiers participating in Gulf war 1 and 2 were sick. A study conducted on nine recently returned soldiers from the New York National Guard showed that nine were expected to have inhaled radioactive dust from exploded DU shells. About every third veteran from the first Gulf War is permanently disabled due to DU effect, and 179,310 veterans of the 592,561 discharged from the 1991 war in Iraq, are receiving disability compensation and another 24,763 cases are pending [14].

Following the invasion of Iraq in 2003, over 140,000 cases of cancer have been reported. They are believed to have been caused by toxic weaponry used by the occu- 
pying troops. It is reported that 2000 tons of (DU) expenditure were used during the invasion [21,35]. In addition, it has resulted in many grossly deformed children born in areas such as southern Iraq where tons of DU have contaminated the environment and local population. An untold number of children of Americans veterans have been born with severe defects as a result of DU contamination. Babies whose fathers served in the 1991 Gulf war are 50 percent more likely to have physical abnormalities; and 40 percent increased risk of miscarriage among women whose partners served in the war was found [14].

Physical abnormality is increasing after the Gulf war where of 13,191 pregnancies among the partners of male Gulf vets, 686, or 5.2 percent, had some form of physical abnormality, compared with 342 , or 3.5 percent, of the 9758 non-Gulf pregnancies [36]. Doctors in Iraq diagnosed severe leukemia in some of the soldiers of which 38 died a few hours after returning home to Lima, Peru. They had leukemia because of exposure to DU and one of them had served in the Baghdad Green Zone area [19].

Near Baghdad, where bunker buster bombs and munitions had exploded, the readings of Geiger counters in 2003 were 1000 and 1900 times the normal reading. These bombs contained more than one ton of DU. According to IAEA half a million soldiers and civilians were dead between 1991 and 1997. Furthermore, it was estimated that 700 - 800 tons of DU were used in the bombing of the military zone south of Basrah, this amount being sufficient to cause 500,000 victims which might lead to death [21]. Almuqdadi [13] stated that the United Kingdom Atomic Energy Authority (UKAEA) warned the British Government of the use of DU weapons in the Gulf war. Such weapons lead to cancer and threat the life of humans near the destroyed equipment [37]. Almuqdadi [13] further mentioned that the American Defense Nuclear Agency warned for serious consequences due to the use of DU weapons. Nick Cohen [38] reported that the amount of DU present in Kuwait and South of Iraq is capable of killing 5,000,000 people. Almuqdadi [15] stated that New York Times in 1992 and other researchers confirmed the effect of DU on the people in the Gulf area.

The Ministry of Environment of Iraq (MOEN) [39] published a report summarizing the radioactive wastes in Iraq (Table 2). It should be mentioned however that these figures represent low estimates [24,25,30,40-42].

The Iraqi Government did some effort to clean up the country but it was very limited. The Ministry of Environment and Ministry of Science and Technology are supposed to work out a plan to get rid of the military scrap contaminated with DU. The contaminated location were pin pointed by IEA and a plan was made to clean these sites [43]. Almuqdadi [30] stated that the Iraqi
Table 2. Preliminary data on radioactive contamination in Iraq including DU [39].

\begin{tabular}{cc}
\hline Radioactive contamination & Quantity (ton) \\
\hline Solid & 500 \\
Liquid & 270 \\
Scrap and soil & Unspecified \\
\hline
\end{tabular}

Government tried to melt the military scrap and reuse it. Later they tried to sell the scrap to neighboring countries. Some of the scrap was exported to Jordan but it was sent back to Iraq because the Jordanian authorities discovered that it was radioactive.

Alobaidy [44] wrote that in 1991 a specialist in DU affairs mentioned that the DU ammunition used in Iraq in 1991 was 940,000 $30 \mathrm{~mm}$ bullets and 14,000 artillery grenades and bombs. He added that 3700 sites were destroyed of which 1400 contained DU and he also stated that the British forces used 100 tons of DU in Basrah during 2003 military operations. In 2005 the presence of thousands of tons of military scrap in Basrah area was reported and Ahamd [45] stated that the scrap amounted to 87,816 tons. New sites contaminated by DU are continuously discovered [46]. Certain reports indicate that scrap removal operations have been stopped for technical reasons [47].

Iraq is littered with expended munitions projectiles, DU destroyed equipment, debris and wind-driven DU dust. Despite the danger and various hazards caused by DU no serious action has yet been taken to clean these hazardous materials [48].

It should be mentioned, however, that United Nations environmental cleanup specialists asked US and British officials for information on locations where the munitions were fired in Iraq, but they only reported DU firing coordinates from Britain [22].

\section{POSSIBILITIES TO DISPOSE RADIOACTIVELY CONTAMINATED SOIL AND SCRAP WITH CRITICALLY HIGH CHRGES}

\subsection{Principles}

In solid waste management "Reuse, Recycle and Recover" are the basic principles used to minimize the quantity of solid waste while burial of solid waste is final solution to be used $[49,50]$. The burial of solid waste requires careful site selection and safe design of the landfill to safeguard the population and environment.

USEPA [51] sub-grouped hazardous waste into two groups referred to as characteristic and listed wastes. The characteristic waste exhibit hazardous behavior (e.g. ig- 
nitability, corrodibility, reactivity and toxicity) while listed waste are rest products of specific industrial waste stream. Depending on the activity level, radioactive waste is divided into four groups [52].

For radioactive waste the landfill should be capable of storing the waste for a long period of time in geological repositories [53].

Generally these landfills contain final cover (including top liner), a bottom liner and leaching removal and collection system (LRCS) [54]. Liners are usually constructed from compacted clays or they can be used as geosynthetic clay sheets [54].

These liners play an important role to isolate the waste for a long period of time. Characteristics of the clay to be used is well discussed [53-59].

\subsection{Landfill Site Selection Criteria}

There are no internationally adopted standards to be followed for site selection criteria [60-62]. Landfill site selection is a complicated process involving several factors like environmental economics and socio economics) $[63,64]$. It should be capable of disposing waste in a safe manner that should provide high degree of protection to human health and environment $[61,65,66]$. However, despite the differences of the techniques or methods to be followed, the end result is to minimize: the risk of public health, impact on the environment, level of services to the facility users and cost to the facility.

General exclusionary criteria for proper landfill sites were suggested by the World Health Organization (WHO), including rechargeable areas, soil profile and characteristics, structure type, natural resources, natural hazards, historic areas, built-up areas, and cultural resources [67]. Water resources are considered as the main factor in terms of environmental protection [68]. Airports, floodplains, wetlands, fault areas, seismic impact zones and unstable areas are considered as unsuitable while land ownership is considered as a conditional criterion. These constraint factors should be considered in early stages of the site selection process of the landfill $[66,68]$. In some countries there are legislation or general policies or guidelines that could be applied directly for locating landfill sites while in others (e.g. Iraq) is does not exist. In such cases, legislation, general policies or guidelines can be adopted from other countries and applied elsewhere [63, $69,70]$. To minimize the potential effect of landfills on adjacent areas and to satisfy defined site selection criteria, a buffer zone is proposed around the potential landfill site $[68,71,72]$.

Site selection criteria from different authors have been collected $[28,61,67,69,73-79]$. On reviewing the factors used by various authors it seems that the most suitable criteria to be used are the following (cf. Table 3):
Table 3. Data sets required for the landfill site selection process.

\begin{tabular}{cc}
\hline Constraint & Distances and specifications \\
\hline Built-up area & $\begin{array}{c}\text { Sites located within the following distances are } \\
\text { preferred for landfill sites } 5 \mathrm{~km} \text { to } 10 \mathrm{~km}\end{array}$ \\
Airports & $>5 \mathrm{~km}$ \\
Public parks and \\
recreation areas \\
Wells \\
Wadis \\
$\begin{array}{c}\text { Depends on the topography and the } \\
\text { prevailing wind direction }\end{array}$ \\
Ground water table \\
Soil \\
Ponds \\
Faults \\
Flood plains \\
Roads
\end{tabular}

- Distance from Cities and Towns: In order to minimize the effect of a landfill of hazardous waste on human health it should be located at least $5-10 \mathrm{~km}$ from the nearest town;

- Distance from Airports: To overcome birds interrupting aircrafts landing and taking off, it is advisable that the landfill should be at a distance of $5 \mathrm{~km}$ or more away from the runway;

- Distance from primary Highways: The land fill should not be very close to highways and placed suitably with respect to the topography of the area and access to roads. Preferably, it should be located more than 5 $\mathrm{km}$ from the nearest road;

- Distance from Public parks and recreation areas: The distance of the landfill from parks and recreation areas depends on the topography and the prevailing wind direction; 
- Groundwater: The groundwater table should be deep enough (minimum $20 \mathrm{~m}$ ) to prevent leakage to groundwater aquifers. The landfill should be away from groundwater recharge areas. In cases of failure, the ground water flow direction should be in such a direction causing minimum pollution;

- Soil: It is preferable that the existing soil has low permeability $(<10-6 \mathrm{~m} / \mathrm{s})$;

- Flood plain areas: Areas that can be flooded should be avoided. The recommended distance is more than $200 \mathrm{~m}$ depending on the inclination;

- Surface water: The landfills should be at least 200 meters away from streams and stream valleys and 500 $\mathrm{m}$ from ponds or lakes;

- Topography: The land fill should be located in an area where surface water is discharged off from it. In addition the landfill site should not be located in an area where erosion by flowing water can take place. Preferably the slope is less than 1:5;

- Biodiversity: The site should be located at least 3 kilometers away from protected areas or areas used for breading or presence of animals. It is recommended that the site should be off from borrowing animals;

- Geology: Faulted areas and karsts terrains are to be avoided. Sand dune movements can change the isolating potential of the site and need to be considered and predicted. Areas with rocks having very significant fractures, fracture zones and open joints should be avoided, including also areas having sinkholes or karsts. The recommended distance is more than 100 $\mathrm{m}$ away from such areas;

- Seismicity: The area should be seismically stable. Nearby reservoirs are to be avoided due to possible induced seismicity;

- Meteorology: Rainfall duration and intensity, temperature, humidity and wind speed and direction must be considered in the site selection process.

The priorities of the above conditions will vary from place to another depending on the population distribution, meteorological, geological and hydrological conditions. In view of the above, it is believed that there are three places inside Iraq that can satisfy the above site selection criteria. Keeping in mind that Iraq covers an area of $438,317 \mathrm{~km}^{2}$ of which $60 \%$ is desert, makes it natural to locate hazardous landfills in desert areas. Suitable ones are the Western, Southern and Al-Jazira deserts (Figure 5). It is believed that they fulfill all the requirements for disposing contaminated waste of war.

The Western desert lies west of Iraq (Figure 5). It covers an area of $104,000 \mathrm{~km}^{2}$. Most of it is slightly rising westwards. The general increase in gradient from east to west is $5 \mathrm{~m} / \mathrm{km}$. It is dissected by frequent valleys. Some of them are canyon-like, running for tens of kilometers.

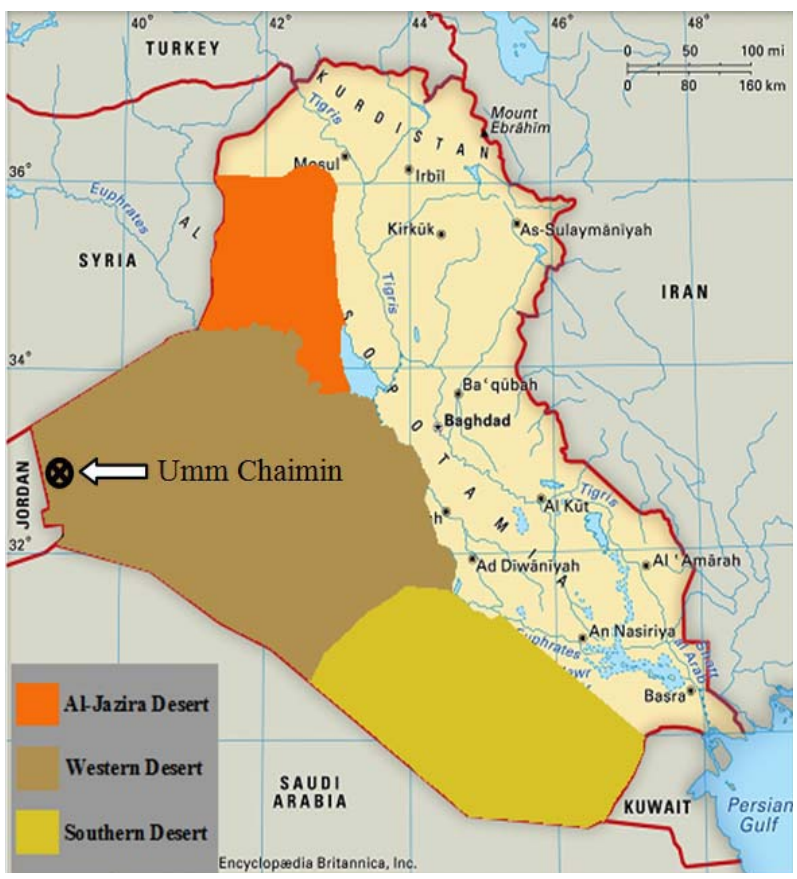

Figure 5. Western, southern and Jezera deserts in Iraq.

Isolated hills are noticed within the area and they can be as high as 50 meters. Depressions are also found, either erosional or due to solution effects. The annual rainfall is low, ranging from $100-150 \mathrm{~mm}$ [80]. The mean annual temperature is ranging from $13^{\circ} \mathrm{C}$ to $30^{\circ} \mathrm{C}$ [80].

The southern desert (Figure 5) covers an area of $76,000 \mathrm{~km}^{2}$ and this area is generally flat and rising toward the south. It is characterized by few hills and has a large number of very long valleys. A fault escarpment which runs for few kilometers with a height of $5-15$ meters is major feature in this desert. The area is characterized by its low rainfall which ranges from 75 to 100 $\mathrm{mm} /$ year [81]. The mean annual temperature is $24^{\circ} \mathrm{C}$ $26^{\circ} \mathrm{C}$.

The Al-Jazira desert covers an area of $29,270 \mathrm{~km}^{2}$, which represents about $6.7 \%$ of the total area of Iraq (Figure 5). This desert covers an area of 29,270 (Figure 5). It is located in the northern part of Iraq within the area bordered by the Tigris and Euphrates Rivers. The mean annual temperature is $30^{\circ} \mathrm{C}-33^{\circ} \mathrm{C}$, while the mean annual amount of evaporation is $3000-3200 \mathrm{~mm}$ [82]. Rainfall occurs during winter in the area, increasing from the south to the north within the area. It is $150 \mathrm{~mm}$ in the south, $200-300 \mathrm{~mm}$, in the enter increasing gradually to $400 \mathrm{~mm}$ in the north. The potential of evaporation in the area is several times higher than the average rainfall [82]. From tectonics points of view, most of the Al-Jazira province lies within the stable shelf area [83].

According to [84] none of the deserts contain major discontinuities or damaged zones but minor discontinuities, including fracture zones, are frequent. Historical 
study of earthquake events in Iraq also indicates that large parts of the desert areas have not experienced any major earthquakes in the past and the rest have only been exposed to a few, moderately strong earthquakes [84].

\subsection{The UMM Chaimin Depression, A Possible Candidate for Disposing Hazardous Waste Including DU}

The Umm Chaimin is a topographic depression, almost circular in shape. Its longest diameter is about 2.9 $\mathrm{km}$ (N-S direction) while the shortest is $2.5 \mathrm{~km}$ long (E-W direction). It is $38 \mathrm{~m}$ to $28 \mathrm{~m}$ deep and located 95 $\mathrm{km}$ southwest Rutbah city in the western desert (Figures 6-8).

The area surrounding the basin is flat. White and White [85] measured the area of the top of the depression at the top closed contour line ( 850 m.a.s.l.) and found it to be $5.73 \mathrm{~km}^{2}$ and they stated that the ratio of the diameter at the ground surface of the depression to the diameter at the bottom of the depression is 1.6 (Figure 7). The total volume of the depression is $0.10953 \mathrm{~km}^{3}$ [86].

The rocks of the area surrounding the depression are of Eocene age of Ratga Formation [87]. They are about $40 \mathrm{~m}$ thick and composed of bedded limestones and dolomitic limestones with some beds of marls and chert. The beds are almost horizontal and there are two faults 5 and $12 \mathrm{~km}$ north of the depression, separating the area in E-W direction [86]. A more detailed description of the tectonic setting is given by [87]. From the seismic point of view the area is stable and the nearest earthquake epicenter (magnitude 4 - 5 degrees on Richter scale) located $120 \mathrm{~km}$ east of the depression [88] and the depression is located within the stable shelf of the Arabian Platform $[84,89,90]$.

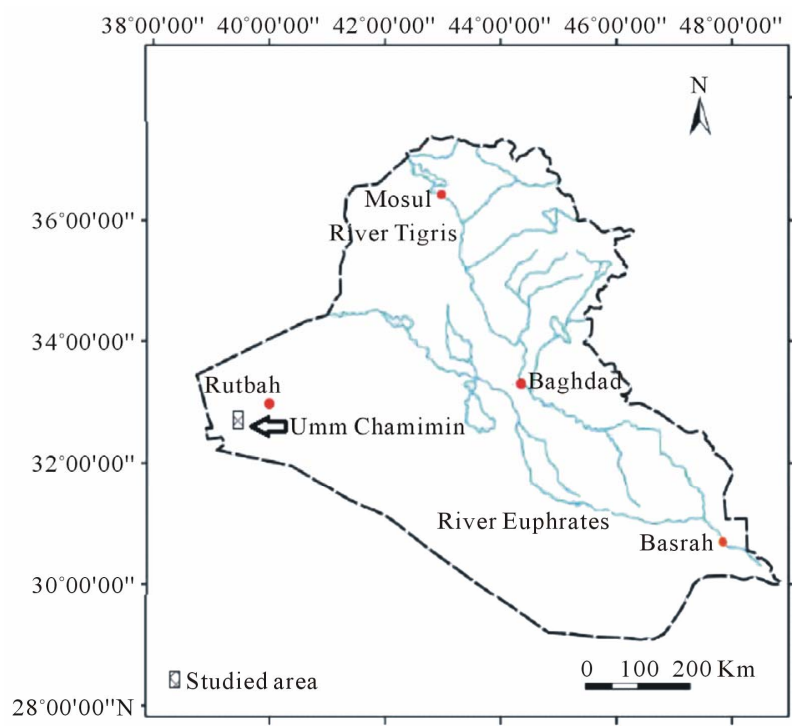

Figure 6. Location of Umm Chaimin.

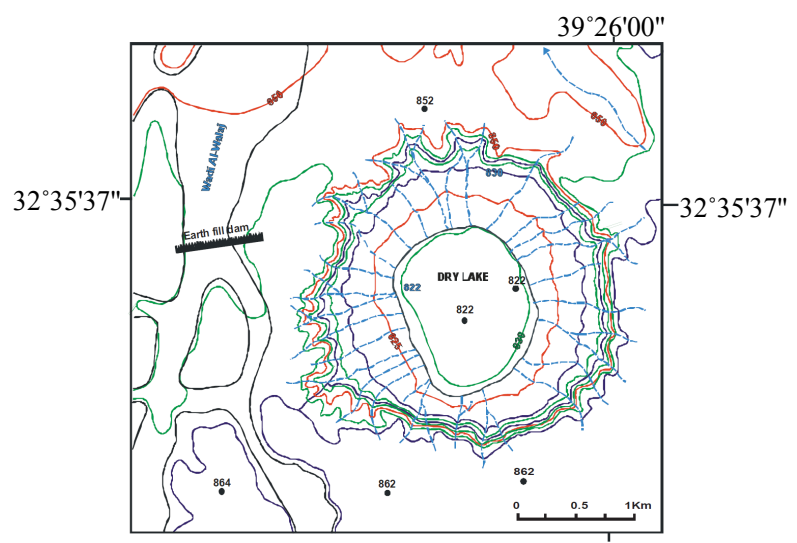

Figure 7. Topography of Umm Chaimin.
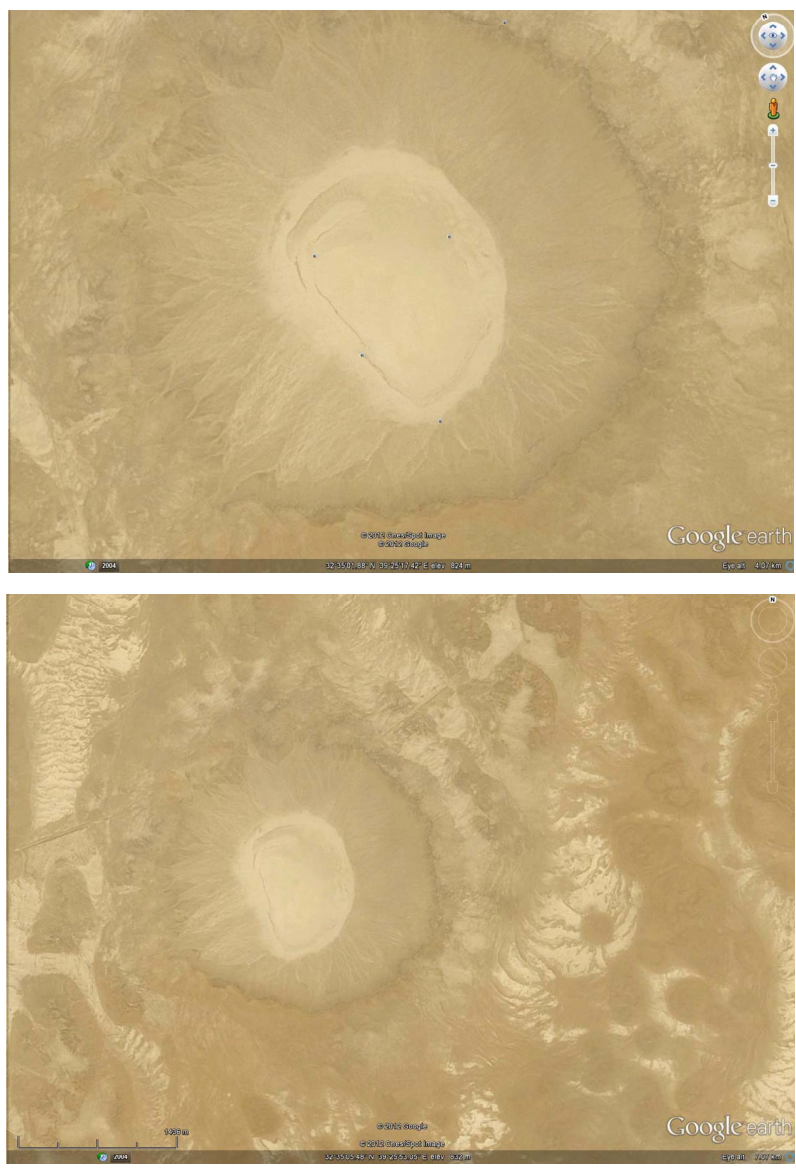

Figure 8. Satellite images of Umm Chaimin.

The floor of the depression is composed of Quaternary sediments to depth of $72 \mathrm{~m}$ followed by limestones and claystones of Paleocene or Late Cretaceous age [91,92]. Jassim [93] described the Quaternary sediments as compact fine illite clay underlain by $30 \mathrm{~m}$ of breccia. As to the rocks on the rim of the depression, Jassim [91] described them from the top to the bottom as $10 \mathrm{~m}$ of silicified limestone interbedded with dolomitic limestones, followed by $20 \mathrm{~m}$ of very coarse crystalline limestones. 
The uppermost meter of the sediment contains Nummulites of Early Eocene age. The drainage pattern is centripetal with $40^{\circ}-60^{\circ}$ dipping off the depression [86]. The peculiar shape of the depression attracted a number of researchers to investigate its origin. Marriam and Holwerda [94] thought that it is of meteoric origin. Later, Mitchell [95] flowed by Al-Naqib [96] thought the depression to be of volcanic origin. Al-Din et al. [97] stated that groundwater action on the limestones created the depression and this idea was supported by Blizkosky [98].

Hagopian [87] suggested that the depression was created due to a gas explosion during the Quaternary period. This idea was also stated by Jassim [91] and Al-Hashimi [92] and Jassim and Buday [90]. Sissakian and Jabbar [86] had compiled all the work and re-analyzed the reports and samples of the bore holes drilled by the Iraqi Geological Survey.

They used remote sensing and GIS technique to evaluate all previous work and concluded that the depression is most probably of karst origin developed within the limestones of the Ratga Formation (Eocene) and possibly in gypsum and anhydrite beds, causing collapse of the roof. They also estimated the age of the depression to be Early-Late Pleistocene.

From the point of geological history, role in hydrology and robustness of the rocks it we claim that Umm Chaimin fulfills all the requirements for being used for disposal of hazardous waste in Iraq. It can accommodate all the military waste, radioactive building waste and radioactive soil.

\subsection{Design to Be Used}

The necessary prerequisites for using the Umm Chaimin depression are 1) that the slopes are stable in the waste-filling period, 2) that the exogenic conditions including climate and seismics prevail in the waste-filling period, and that these conditions are not changed dramatically thereafter.

The proposed principle is to use the sandwich-principle introduced through an EU project some years ago for disposal of hazardous chemical waste in big rooms in abandoned mines, and to cover the waste mass by a tight top construction shaped so that practically all rainwater is discharged. The waste must be in solid, dry form or solidified by mixing with suitable cement or smectitic soil. It shall be placed layerwise by tractors without adding water, and compacted by modern rollers that give high dynamic impact.

The layer thickness is selected with respect to the type and size of the waste objects requiring simple sorting, disarmament, and destruction. This should include compression of cars, tubes, containers and cisterns in a plant located on the ground surface at the rim of the depression where the slope is steep. The waste is brought down by elevators to the level where placement shall be made. A first sorting is made on the ground surface so that the same type of waste can be contained in certain layers placed on freshly cast concrete, and filled with and covered with concrete. The surface of the waste being placed shall have sufficient inclination to let rainwater be discharged to temporary cavities kept drained by effective pumps. Every tenth layer shall consist of in-situ compacted clayey soil, which is also placed at the walls of the depression, thereby eliminating migration of moisture from the ground into the waste fill. This type of sandwiching delays water saturation of the waste to become significant for hundreds of thousands of years.

When the depression has finally been filled, which may well involve partial filling with sand from the surroundings, the upper surface should be slightly upward conical. The uppermost layer should be crushed rock serving as an effective drainage and as protection from wind- and water-erosion. It shall rest on one or a few meters of sand and silt, which should in turn cover a layer of a few decimeters of tight clay with suitable grain size composition and content of smectite minerals. The whole top cover should have, in principle, the same constitution as presently constructed landfills in the rest of the world.

The aim is to reach total isolation of radioactive and hazardous chemical waste for any period of time provided that the climatic conditions remain reasonably constant at reasonable cost. However, even if these conditions tend to be like the present ones in northern Europe, i.e. rainy and chilly, water saturation of the waste mass will take many tens of thousands of years. Radionuclides will be sorbed by the clay component and never reach the biosphere. This can all be achieved at minimum cost by:

- Using very cement-poor concrete of the types. The cement can be either of Portland type or of low-pH type keeping in mind the chemical interaction of the concrete and steel and other metals;

- Using national Iraqi clay materials with suitable content of expanding minerals (smectite). Such clays have been identified by [12]. Special care is taken to select clays with optimal granulometry and smectite content for maintaining their isolation capacity for very long periods of time;

- Using technologies emanating from long practical experience in applied engineering geology comprising also methods for predicting the physical and chemical maturation of the cement-based waste embedment and of the effective clay seals;

- From the point of geological history, role in hydrology and robustness of the rocks it we claim that Umm Chaimin fulfills all the requirements for being used 
for disposal of hazardous waste in Iraq. It can accommodate all the military waste, radioactive building waste and radioactive soil. The placement of waste and isolations can be made in one sequence or stepwise over many years.

- Demonstrating the capacity to isolate radioactive waste from the biosphere by referring to performed large-scale tests and to the models of performance of concrete and clay.

\section{CONCLUSION}

The need for effective isolation of radioactively contaminated soil and equipment caused by the Iraqi wars for minimizing the huge risk for the health of the Iraqi population is enormous as illustrated by the present study. This can be achieved by using rather simple and cheap techniques assuming that waste can be transported in shielded form to the proposed site Umm Chaimin. Here, already worked out technical principles for isolation of the waste can be applied, leading to safe containment of the waste for hundreds of thousands of years even if significant climatic changes take place.

\section{REFERENCES}

[1] Pearce, D. and Walker, Ch. (1996) Sustainable development. In: Baily, R., Ed., Water and Environmental Management in Developing Countries, Amazon Company, UK.

[2] Jackson, B. (1996) International institutions. In: Baily, R., Ed., Water and Environmental Management in Developing Countries.

[3] Aldiab, S. (2000) The gap between planning and execution of environmental policies in Jordan: A case study of Jordan valley. M.A. Thesis, Al al-Bayt University, Jordan.

[4] Chandak, S.P. (2010) Trends in solid waste management: Issues, challenges and opportunities. International Consultative Meeting on Expanding Waste Management Services in Developing Countries, Tokyo, 18-19 March 2010.

[5] Abdel Rahman, R., Ed. (2012) Radioactive waste. Tech Publishing, Croatia, 219.

[6] IAEA (1995) The principles of radioactive waste management. Safety Series, 111-F, International Atomic Energy Agency, Vienna.

[7] IAEA (2002) Long term storage of spent nuclear fuelSurvey and recommendations. Final report of a coordinated research project, 1994-1997. TecDoc-1293, International Atomic Energy Agency, Vienna.

[8] IAEA (2010) Setting authorized limits for radioactive discharge: Practical issues to consider.

[9] Yagasaki, K. (2003) Depleted uranium shells, the radioactive weapons-Perpetuation of war damage by radiation, group of peace education against nuclear weapon. The World Uranium Weapons Conference, University of the Ryukyus, August 2003.
[10] Reeves, D.M., Parashar, R. and Zhang, Y. (2012) Hydrogeologic characterization of fractured.

[11] IAEA (2011) Nuclear technology review 2011. IAEA/ NTR/20011, Vienna.

[12] ICBUW (2008) International coalition to ban uranium weapons, European Parliament passes far reaching DU resolution in landslide vote.

http://www.bandepleteduranium.org/en/a/181.html

[13] Al-Muqdadi, K. (2000) Discovery of DU effects is a humanitarian mission. Althakafa Aljadeda Magazine, 296 (in Arabic).

[14] Bollyn, C. (2004) The real dirty bombs: Depleted uranium.

http://www.erichufschmid.net/TFC/Bollyn-Uranium-IraqVets.html

[15] Wagner, F. and Thurn, V. (2005) The doctor, the depleted uranium and the dying children, documentary film produced for German television and released by OchoaWagner production in 2004 in Germany, exposes the use and impact of radioactive weapons during the current war against Iraq.

http://www.grassrootspeace.org/depleted_uranium_iraq.ht $\underline{\mathrm{ml}}$

[16] Rowe, D.G. (2003) Depleted uranium casts a shadow over peace in Iraq. The New Scientist Magazine, 2391.

[17] Durakovic, A. (2003) Undiagnosed illnesses and radioactive Warfare. CrOATIAN Medical Journal, 44, 520-532.

[18] Puppetgov (2009) Radioactive US weapons taking toll in Iraq.

http://www.puppetgov.com/2009/08/24/radioactive-us-we apons-taking-toll-in-iraq/http://www.puppetgov.com/2009 /08/24/radioactive-us-weapons-taking-toll-in-iraq/

[19] Hall, I.W. (2006) Depleted uranium for dummies. http://iaea.org/Publications/Reports/ntr2011.pdf http://www.notinkansas.us/du 3.html http://www.umrc.net/news_archive.aspx?year=2004 http://www.zcommunications.org/du-and-the-liberation-o f-iraq-by-christian-scherrer,Life

[20] Alshakhly, M. (2003) Radioactive uranium threatens Iraq: Level of radiation pollution is 30,000 the accepted level. Journal of Environment and Development, 69 (in Arabic).

[21] Ross, S. (2008) We are living through another Hiroshima. Iraqi doctor says, uruknet.info, informazione dal medio oriente information from Middle East. http://www.uruknet.de/?p=m42361\&hd $=\&$ size $=1 \& 1=e$

[22] Williams, T.D. (2008) Flashback: The depleted uranium threat. http://www.truthout.org/article/the-depleted-uranium-thre at

[23] UMRC (2004) Uranium Medical Research Centre reports.

[24] Al-Muqdadi, K. and Al-Ansari, N.A. (2011) The waste of wars in Iraq: Its nature, size and contaminated areas. Workshop on Landfills of Hazardous Waste and Its Implications on Health and Environment, Lulea, 15-17 November 2011, 1-34.

[25] Al-Muqdadi, K. and Al-Ansari, N.A. (2011) Depleted uranium: Its nature, characteristics and risks of the mili- 
tary uses on humans and the environment. Workshop on Landfills of Hazardous Waste and Its Implications on Health and Environment, Lulea, 15-17 November 2011.

[26] Al-Daghastani, H. (2011) Using reflection anomalies to detect radioactive contaminations in Nineveh governorate Northern Iraq. Workshop on Landfills of Hazardous Waste and Its Implications on Health and Environment, Lulea, 15-17 November 2011, 35-51.

[27] Al-Ansari, N.A., Pusch, R., Knutsson, S. and Al-Muqdadi, K. (2011) Effective isolation of radioactive military wastes in Iraq-A necessary humanitarian action. Workshop on Landfills of Hazardous Waste and Its Implications on Health and Environment, Lulea, 15-17 November 2011, 52-71.

[28] Al-Ansari, N.A., Al-Hanbali, A. and Knutsson, S. (2012) Locating solid waste landfills in Mafraq City, Jordan. Journal of Advanced Science and Engineering Research, 2, 40-51.

[29] Chulov, M. (2010) Iraq littered with high levels of nuclear and dioxin contamination, study finds.

[30] Al-Muqdadi, K. (2007) When cleaning radioactively contaminated sites in Iraq? Environment \& Development, 112-113 (in Arabic).

[31] Weyman, T. (2003) Abu Khasib to Al Ah'qaf: Iraq Gulf War II field investigations report. Uranium Medical Research Centre.

http://www.umrc.net/os/downloads/Iraq_report_1.doc

[32] Scherrer, C. (2003) DU and the liberation of Iraq, Christian Scherrer's Z Space page.

[33] Al-Taie, L. (2012) Performance of landfills of hazardous waste with special respect to the function of the clay liner. Licentiate Thesis, Lulea University of Technology, Lulea.

[34] MEMERI (2003) Nuclear scientists in Iraq: Citizens stole uranium and other dangerous materials. The Middle East Media Research Institute, Special Dispatch, 497. http://www.memri.org/report/en/0/0/0/0/0/0/858.htm

[35] Press TV (2010) Radioactive US weapons taking toll in Iraq.

[36] Lorimore, S.A. and Wright, E.G. (2003) Radiation-induced genomic instability and bystander effect: Related inflammatory-type responses to radiation-induced stress and injury? A review. International Journal of Radiation Biology, 79, 15-25.

[37] Arbuthnot, F. (1991) Allies. Shells Leave Deadly Radiation, Scotland on Sunday, 18 March 1991.

[38] Cohen, N. (1991) Radioactive waste left in gulf by allies. The Independent on Sunday, London.

[39] Ministry of Environment of Iraq (MOEN) (2007) Report on the environmental fact in 2007 (published in Arabic). http://www.moen.gov.iq/waq3.html

[40] Al-Muqdadi, K. (2006) Beware of scrap iron from the remnants of war. Environment and Development, 8, 1621.

[41] Al-Muqdadi, K. (2008) Appeal to clean up the Iraq war remains. Environment \& Development, 135 (in Arabic).

[42] Al-Muqdadi, K. (2009) Call to clean Iraq from war remains. Environment and Development, 135, 18-29 (in
Arabic).

[43] Aldistor (2008) Separation of army equipment in contaminated areas of Baghdad. Aldistor Newspaper, Baghdad (in Arabic).

[44] Alobaidy, A. (2005) Ministry of Environment pin points 311 sites contaminated by DU. Alquds Alarabi, 6 (in Arabic).

[45] Ahmad, R. (2010) 87 thousand tons of contaminated scrap in Basrah. Almalaf Press, 26 (in Arabic).

[46] INA (2009) Discovery of new DU contaminated scrap site south Basdrah. Iraq News Agency, 29 (in Arabic).

[47] Aswat Aliraq (2009) Metallurgical state company starts to clean contamination in iron factory. Aswat Aliraq News Paper, 24 (in Arabic).

[48] Zankana, H. (2009) Women in Faloja avoid pregnancy due to the fear of having disabled children. Alkus Alarabi News Paper, London (in Arabic).

[49] Clark, A.C. (1995) Solid, toxic, and hazardous waste environmental science. In: Kemp, M.J., Ed., Environmental Science, 3rd Edition, Wm. C. Brown Publishers, Iova.

[50] Enger, E.D. and Smith, B.F. (1995) Environmental science, a study of interrelationships. 6th Edition, WCB, McGraw-Hill, Washington DC.

[51] EPA (2005) Introduction to hazardous waste identification (40 CFR parts 261). No. EPA 530-K-05-012.

[52] IAEA (1994) Classification of radioactive waste (Safety series No. GSG-1). IAEA, Vienna.

[53] Pusch, R. and Khil, A. (2004) Percolation of clay liners of ash landfills in short and long time.

[54] Al-Taie, L., Al-Ansari, N.A., Knutsson, S. and Pusch, R. (2011) Hazardous wastes problems in Iraq: A suggestion for an environmental solution. Workshop on Landfills of Hazardous Waste and Its Implications on Health and Environment, Luleå University of Technology, Luleå, 15-17 November 2011, 90-108

[55] Pusch, R. (2000) On the risk of liquefaction of buffer and backfill. SKB Technical Report TR-00-18, Stockholm.

[56] Pusch, R. and Yong, R.N. (2006) Microstructure of smectite clays and engineering performance (electronic resource). Taylor \& Francis, London, New York.

[57] Pusch, R., Kasbohm, J., Pacovskt, J. and Cechova, Z. (2010) Chemical stability of montmorillonite buffer clay under repository-like conditions-A synthesis of relevant experimental data. Applied Clay Science, 47, 113-119. doi:10.1016/j.clay.2009.01.002

[58] Pusch, R., Malmborg, B. and Strandljung, K. (2011) Example of construction of very tight clay liners - The Högbytorp case. Workshop on Landfills of Hazardous Waste and Its Implications on Health and Environment, Luleå University of Technology, Luleå, 15-17 November 2011, 72-89.

[59] Pusch, R. and Weston, R. (2012) Superior techniques for disposal of highly radioactive waste (HLW). Progress in Nuclear Energy, 59, 75-85. doi:10.1016/i.pnucene.2012.01.005 
[60] Malczewski, J. (1999) GIS and multicriteria decision analysis. John Wiley \& Sons, Inc., New York.

[61] Dikshit, A.K., Padmavathi, T. and Das, R.K. (2000) Locating potential landfill sites using geographic information system. Journal of Environmental Systems, 28, 43-54. doi:10.2190/PMU7-1H8M-LVJQ-R16T

[62] Lin, H.Y. and Kao, J.J. (1999) Enhanced spatial model for landfill siting analysis. Journal of Environmental Engineering, 125, 845-852. doi:10.1061/(ASCE)0733-9372(1999)125:9(845)

[63] Kao, J.J. and Lin, H.Y. (1996) Multi factors spatial analysis for landfill siting. Journal of Environmental Engineering, 122, 902-907. doi:10.1061/(ASCE)0733-9372(1996)122:10(902)

[64] Tammemagi, H. (1999) The waste crisis: Landfill, incinerators, and the search for a sustainable future. Oxford University Press, Oxford, 279.

[65] Siddiqui, M.Z., Everett, J.W. and Vieux, B.E. (1996) Landfill siting using geographic information system: A demonstration. Journal of Environmental Engineering, 122, 515-523. doi:10.1061/(ASCE)0733-9372(1996)122:6(515)

[66] Oweis, I.S. and Khera, R.P. (1998) Geotechnology of waste management. 2nd Edition, PWS Publishing Company, Boston.

[67] Sloan, W.M. (1993) Site selection for new hazardous waste management facilities. WHO European Publications European Series, 46, World Health Organization, Copenhagen.

[68] Petts, J. and Eduljee, G. (1994) Environmental impact assessment for waste treatment and disposal facilities. John Wiley, Chichester, 342.

[69] Basagaoglu, H., Celenk, E., Marino, M.A. and Usula, N. (1997) Selection of waste disposal sites using GIS. Journal of the American Water Resources Association, 33, 455464. doi:10.1111/j.1752-1688.1997.tb03524.x

[70] Kao, J.J., Chen, W.Y., Chen, W., Lin, H. and Guo, S. (1996) Network expert geographic information system for landfill siting. Journal of Computing and Civil Engineering, 10, 307-317. doi:10.1061/(ASCE)0887-3801(1996)10:4(307)

[71] Bonham-Carter, G.F. (1994) Geographic information systems for geoscientists: modelling with GIS. Pergamon, Oxford.

[72] Hussey, V., Dodd, V.A. and Dennison, G.J. (1996) Locating a landfill site for Dublin using geographic information systems. Proceeding of the Institution of Civil Engineers-Municipal Engineer, 115, 125-133. doi:10.1680/imuen.1996.29147

[73] Kao, J.J., Lin, H.Y. and Chen, W.Y. (1997) Network expert geographic information system for landfill siting. Journal of Waste Management \& Research, 15, 239-253.

[74] Baban, M.J. and Flannagan, J. (1998) Developing and implementing GIS-assisted constraints criteria for planning landfill sites in the UK. Journal of Planning \& Research, 13, 139-151.

[75] Melbourne and Metropolitan Board of Works (1985) Offsite industrial waste storage treatment and disposal facili- ties: Proposed siting criteria. Melbourne and Metropolitan Board of Works, Australia.

[76] Ministry of Water, Land and Air Protection-Canada (1993) landfill criteria for municipal solid waste.

http://www.gov.bc.ca/epd/epdpa/mpp/lcmsw.htm

[77] Cheremisinoff, N.P. (2003) Handbook of solid waste management and waste minimisation technology. Elsevier Science, New York, 477.

[78] Batstone R., Smith J.E.J. and Wilson, D. (1989) The safe disposal of hazardous waste: The special needs and problems of developing countries. Vol. I, II and III, The World Bank Technical Papers, Washington DC.

[79] Al-Meshan, O. (2005) Location criteria for domestic and hazardous waste disposal to landfill in the Jordanian Badia using GIS. PhD Thesis, Coventry University, Coventry.

[80] Sissakian, V.K. (2007) General information. Iraqi Bulletin of Geology and Mining, 3, 5-8.

[81] Ma'ala, K.A. (2009) Geomorphology. Iraqi Bulletin of Geology and Mining, 5, 5-32.

[82] Ma'ala, K.A. (2009) General information. Iraqi Bulletin of Geology and Mining, 3-4.

[83] Fouad, S. and Nasir W. (2009) Tectonics and structural evolution, geomorphology. Iraqi Bulletin of Geology and Mining, 5, 33-48.

[84] Alsinawi, S.A. (2006) Seismicity. In: Jassim, S.Z. and Goff, J.C., Eds., Geology of Iraq, Dolin Publ., Praque and Moravian Museum, 84-90.

[85] White, W.B. and White, E.L. (2006) Size scales for closed depressions landforms. Speleologenesis and Evaluation of Karst Aquifers, The Online Scientific Journal, Internet data.

[86] Sissakian, V.K. and Jabbar, M.F.A. (2008) Using remote sensing and GIS techniques in detecting the origin of Umm Chaimin depression. West Iraq. Iraqi Bulletin of Geology and Mining, 4, 51-72.

[87] Hagopian, D.H. (1979) Regional geological mapping of Nahidain-Tinif area. Iraqi Geological Survey Report No. 983.

[88] Scientific Research Council (1985) Seismological map of Iraq.

[89] Al-Kadimi, J.A.M., Sissakian, V.K., Fattah, A.S. and Deikran, D.B. (1996) Tectonic map of Iraq.

[90] Jassim, S.Z. and Buday T.B. (2006) Units of the stable shelf. In: Jassim, S.Z. and Goff, J.C., Eds., Geology of Iraq, Dolin Publ., Praque and Moravian Museum, 57-70.

[91] Jassim, S.Z. (1980) Umm Chaimin depression, Western Desert. Iraqi Geological Survey Report.

[92] Al-Hashimi, H.A. (1982) Contribution to the origin of Umm Al-Chaimin depression, Western Desert. Journal of the Geological Society of Iraq, 15, 35-39.

[93] Jassim, S.Z. (1981) Excursion guide to the Western Desert of Iraq. 6th Iraqi Geological Congress, Baghdad, 28-31.

[94] Marriam, R. and Holwerda, J.G. (1957) Al-Umchaimin, a crater of possible meteoritic origin in Western Iraq. The 
Geographical Journal, 123, 231-233.

doi: $10.2307 / 1791323$

[95] Mitchell, R.C. (1958) The Al-Umchaimin crater, Western Iraq. The Geographical Journal, 124, 578-580.

[96] Al-Naqib, K.M. (1967) Geology of the Arabian Peninsula. USGS Professional Paper, 560-g, 54.
[97] Al-Din, T.S., Al-Sanawi, S.A. and Matolin, M. (1970) Al-Umm Chaimin depression, Western Iraq. Not an Astrobleme. Journal of the Geological Society of Iraq, III, 1.

[98] Blizkovisky, M. (1971) Geophysical measurements in the area of Al-Umm Chaimin topographic depression. 